Mini Review

\section{Incidence and disease control of Zucchini yellow mosaic potyvirus}

\section{Mahmoud Hamdy Abd El-Aziz*}

Plant Pathology Institute, Agricultural Research Center, Alexandria, Egypt

\section{Abstract}

Zucchini yellow mosaic potyvirus (ZYMV) was first identified in northern Italy. It likes other species of the family Potyuiridue. ZYMV has been recorded in many countries since 1981. The efficient intercontinental spread of the virus can be explained by international trading of infected seeds. Since coat protein (CP) analysis has become a primary method for taxonomic assignment of potyviruses the aims were to characterize this genomic region of ZYMV originating from virusinfected cucurbitaceous seedlings. Virus infection in cucurbits is typically associated with mosaic symptoms on leaves and lumpy, distorted fruit. The range of symptoms produced by each virus can overlap and plants are commonly infected by more than one virus at once. The viruses are spread by many species of aphids moving through or within a crop. Control options include: destroying old cucurbit crops as soon as harvesting is completed destroying weeds and volunteer cucurbits, within and around crops as these harbor the viruses and/or the aphids separating new crops from maturing crops as these will have high levels of virus infection avoiding overlapping crops of cucurbits.

\section{Introduction}

Zucchini yellow mosaic virus (ZYMV) is a member of family Potyviridae and is considered the most economically important virus attacking cucurbit plants under field conditions [1]. The virus was isolated for the first time in northern Italy [2]. Soon after, it was identified in areas throughout the world where cucurbits are cultivated, including Mediterranean countries, Japan, Germany, Central Europe, China, Chile, Australia, Mexico, Mauritius, Canada and the USA $[3,4]$. This relatively new, but aggressive virus (member of the potyvirus group) has spread rapidly throughout the world, suggesting an efficient transmission from plant to plant by several aphid species in a non-persistent manner [5] and long distance distribution via infected seeds [6-8]. In Egypt, ZYMV was isolated from naturally infected squash plants [9]. Squash fruits (Figure 1) [1] exhibiting mosaic, blister and stunt symptoms (Figure 2) and squash fruits contain abscess were observed in Egypt. ZYMV like other species of the family Potyuiridue [5] is transmitted by aphids in a non-persistent manner [1]. The efficient intercontinental spread of the virus can be explained by international trading of infected seeds. However, the rate of disease transmission via seed is low and difficult to prove [10-12]. There is some evidence for seed transmission in the case of zucchini [6,7], buttercup squash [8] and hulless oilseed pumpkin $[13,14]$. This work focused on studying the seedborne virus transmission on hulless

\section{More Information}

*Address for Correspondence: Mahmoud Hamdy Abd El-Aziz, Plant Pathology Institute, Agricultural Research Center, Alexandria, Egypt, Tel: +201229556042

Email: maziz70@yahoo.com

Submitted: 10 April 2020

Approved: 04 May 2020

Published: 05 May 2020

How to cite this article: Abd El-Aziz MH. Incidence and disease control of Zucchini yellow mosaic potyvirus. J Plant Sci Phytopathol. 2020; 4: 033-035.

DOI: 10.29328/journal.jpsp.1001048

ORCiD: orcid.org/0000-0002-4604-4063

Copyright: (c) 2020 Abd El-Aziz MH. This is an open access article distributed under the Creative Commons Attribution License, which permits unrestricted use, distribution, and reproduction in any medium, provided the original work is properly cited.

Keywords: ZYMV; Cucurbits; Seedlings; Aphids; Squash; Pumpkin

Check for updates OPEN ACCESS

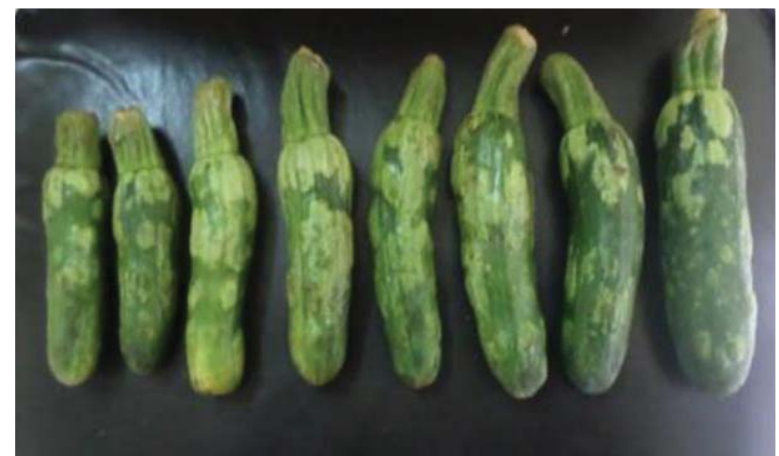

Figure 1: ZYMV on squash fruits.

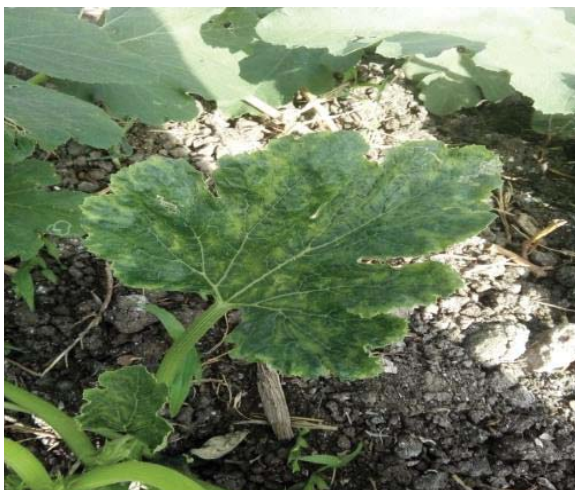

Figure 2: ZYMV on squash leaf. 
oilseed pumpkin, the effect of storage time on the rate of virus transmission via infected seeds, and characterization of the virus isolates transmitted by seeds. Since coat protein (CP) analysis has become a primary method for taxonomic assignment of potyviruses the aims were to characterize this genomic region of ZYMV originating from virus-infected cucurbitaceous seedlings [15]. Virus infection in cucurbits is typically associated with mosaic symptoms on leaves and lumpy, distorted fruit. The range of symptoms produced by each virus can overlap and plants are commonly infected by more than one virus at once.

\section{The role of aphids in spreading the viruses}

The viruses are spread by many species of aphids moving through or within a crop. The aphids pick up the virus after feeding on infected leaves for only a few seconds and remain capable of spreading the virus for up to several hours after feeding. Winged apahids may be carried several kilometers by wind. In this way, small numbers of aphids are able to successfully spread the viruses to large numbers of plants. As a result, devastating crop losses can occur without significant numbers of aphids being observed. Most commonly, virus is spread by aphid species which do not settle and establish a colony within a crop but move from plant to plant, briefly tasting as they search for suitable host plants $[1,16,17]$.

\section{Disease control}

All viruses can be managed using the same methods. As the greatest yield losses occur when plants are infected early in life, control measures are aimed at delaying and minimizing the levels of virus within crops. No single measure provides complete control and integrating multiple measures will provide better control. Control options include: destroying old cucurbit crops as soon as harvesting is completed destroying weeds and volunteer cucurbits within and around crops as these harbor the viruses and/or the aphids separating new crops from maturing crops as these will have high levels of virus infection avoiding overlapping crops of cucurbits, particularly zucchini arranging sequential plantings so that younger plantings are upwind of older crops separating crops, for example by using blocks of non-susceptible crops using resistant or tolerant varieties. These are available for all three viruses in pumpkin and zucchini using super-reflective plastic mulches, as these deter aphids from landing on leaves and can delay disease development in zucchini and other cucurbit species which do not rapidly cover the mulched area combing super-reflective mulches with weekly applications of stylet oil, applied to cover leaf surfaces thoroughly. Regular insecticide applications generally have little effect on the spread of these viruses, as it usually occurs with very short feeding times. Some insecticides actually increase virus spread as the chemicals agitate the aphids causing more frequent movement and feeding. Virus diseases are a worldwide problem of cucurbits and a major limiting Factor for cucurbit production approximately 35 viruses infecting cucurbits worldwide [18].

\section{References}

1. Abd El-Aziz M.H. The Importance of Potato virus Y Potyvirus. J Plant Sci Phytopathol. 2020; 4: 009-015.

2. Lisa V, Boccardo G, D'Agostino G, Dellavalle G, D'Aquilio M Characterization of a potyvirus that causes zucchini yellow mosaic. Phytopathology. 1981; 71: 667-672.

3. Desbiez C, Lecoq H. Zucchini yellow mosaic virus. 1997; Plant Pathol 46: 809-829.

4. Prieto $\mathrm{H}$, Bruna $\mathrm{A}$, Hinrihsen $\mathrm{P}$, Munoz $\mathrm{C}$. Isolation and molecular characterization of a Chilean isolate of Zucchini yellow mosaic virus. Plant Disease. 2001; 85: 644-648.

PubMed: https://www.ncbi.nlm.nih.gov/pubmed/30823033

5. Lisa $\mathrm{V}$, Lecoq H. Zucchini yellow mosaic virus. CMI/AAB Description of Plant Viruses No. 282. Kew, Surrey (GB). 1984.

6. Davis RF, Mizuki MK. Seed transmission of zucchini yellow mosaic virus in squash. Phytopathology. 1986; 76: 1073.

7. Schrijnwerkers CCFM, Huijberts N, Bos L. Zucchini yellow mosaic virus: two outbreaks in the Netherlands and seed transmissability. Neth J PI Path. 1991; 97: 187-191

8. Fletcher JD, Wallace AR, Rogers BT. Potyviruses in New Zealand buttercup squash (Cucurbita maxima Duch.): yield and quality effects of ZYMV and WMV2 virus infections. New Zealand J Crop Horticult Sci. 2000; 28: 17-26.

9. Fath-Allah MM, Ahmed AE. Sensitive detection of watermelon mosaic and zucchini yellow mosaic viruses from infected squash plants using serological methods and polymerase chain reaction. Egy $J$ Experimental Biol (Bot.). 2011; 7: 179 - 185.

10. Provvidenti R, Robinson RW. Lack of seed transmission in squash and melon plants infected with zucchini yellow mosaic virus. Cucurbit Genet Coop Rpt. 1987; 10: 81.

11. Gleason ML, Provvidenti R. Absence of seed transmission of zucchini yellow mosaic virus from seed of pumpkin. Plant Disease. 1990; 74 828.

12. Robinson RW, Provvidenti R, Shail JW. Tests for seed born transmission of Zucchini yellow mosaic virus. Hortscience. 1993; 28 : 694-696

13. Burgmans $\mathrm{J}$, Fletcher J. Virus infections levels of oilseed pumpkin in New Zealand. Cucurbit Genet Coop Rpt. 2000; 23: 112-113.

14. Tóbiás, I.and Kovács G. Seed transmission of zucchini yellow mosaic virus - new viral pathogen - on cucurbitaceous plants. Növényvédelem (Plant Protection). 2001; 37: 29-31 (in Hungarian).

15. Choi SK, Choi JK, Park WM, Ryu KH. RT-PCR detection and identification of three species of cucumoviruses with a genus-specific single pair of primers. J Virol Methods. 1999; 83: 67-73. PubMed: https://www.ncbi.nlm.nih.gov/pubmed/10598084

16. Sammons B, Barnett OW, Davis RF, Mizuki MK. A survey of viruses infecting summer squash in South Carolina. Plant Disease. 1989; 73 : 401-404

17. Schrijnwerkers CCFM, Huijberts N, Bos L. Zucchini yellow mosaic virus: two outbreaks in the Netherlands and seed transmissability. Neth J Plant Pathol. 1991; 97: 187-191.

18. Provvident R. Diseases caused by virus. In: "Compendium of cucurbit diseases. (Zitter TA, Hopkns DI, Thomas CE. Eds)", Minnesota, USA, APS Press. 1996; 37-45.

19. Greber R, McLean G, Grice M. Zucchini yellow mosaic virus in three States of Australia. Aust Plant Pathol. 19878; 16: 19-21. 
20. Tóbiás I, Palkovics L. Characterization of Hungarian isolates of zucchini yellow mosaic virus (ZYMV, potyvirus) transmitted by seeds of Cucurbita pepo var. styriaca. Pest Manag Sci. 2003; 59: 493-497. PubMed: https://www.ncbi.nlm.nih.gov/pubmed/12701712

21. Wang HL, Gonsalves D, Provvidenti R, Zitter TA. Comparative biological and serological properties of four strains of zucchini yellow mosaic virus. Plant Disease. 1992; 76: 530-535.

22. Abd El-Aziz MH. Natural infection of squash fruits (Cucurbita pepo) by
Zucchini Yellow Mosaic potyvirus (ZYMV) in Alexandria governorate. J Plant Sci Phytopathol. 2020; 4: 028-032.

23. Al-Shahwan IM. First report of zucchini yellow mosaic virus on cucurbits in the central region of Saudi Arabia. J. King Saud Univ. 1990; 2: 251 260.

24. Vučurović A, Bulajić A, Stanković I, Ristić D, Nikolić D, et al. First Report of Zucchini yellow mosaic virus in Watermelon in Serbia. Plant Disease. 2012; 96: 149.

PubMed: https://www.ncbi.nlm.nih.gov/pubmed/30731890 